\title{
Isolation and molecular characterization of some bacterial pathogens in EI-Serw fish farm, Egypt
}

\author{
Manal I. El-Barbary ${ }^{1}$ and Ahmed M. Hal ${ }^{2}$ \\ 1- Fish Disease Lab, National Institute of Oceanography and Fisheries. \\ 2- Genetics and Genetic Engineering Lab., National Institute of Oceanography and \\ Fisheries. \\ E-mail address: manal278@yahoo.com
}

\section{ABSTRACT}

The current study was carried out to isolate and identify some of bacteria infecting fish of El-Serw fish farm during the harvest season from December to March 2014-2015. Fish samples (155) were collected from different ponds of farm; 65 Nile tilapia (Oreochromis niloticus), 55 catfish (Clarias gariepinus) and 35 mullet (Liza ramada) were used to isolate bacteria in fish organs (gills, liver and kidney) using different selective media, from the examined fish, bacteria belonging to Pseudomonas, Aeromonas and Enterobacteriaceae were isolated. The group most frequently isolated from fish was Aeromonas, the highest number of putative Aeomonas isolates were obtained from O. niloticus 19 (29\%), followed C. gariepinus $12(21.8 \%)$ and L. ramada $5(14.2 \%)$. Whereas putative Pseudomonas sp. showed fewer prevalence $9(13.8 \%), 8(14.5 \%)$ and $4(11.4 \%)$ from $O$. niloticus, $C$. gariepinus and $L$. ramada, respectively, while only two colonies were recovered from Yersinia Agar Base. Seven isolates were selected and identified by sequencing of 16S rRNA. The analysis of sequence of 16S rRNA gene using universal primers (RW01 and DG74) resulted in the identification of three bacterial isolates of Pseudomonas fluorescens, one of Pseudomonas putida, two of Aeromonas hydrophila and one of Klebsiella oxytoca. The antibiogram test of these isolates revealed their sensitivity to ciprofloxacin, norfloxacin, and gentamycin. This study concluded that the performance $16 \mathrm{~S}$ rRNA assay has the prospective to create an important contribution to infection management providing rapid of identification the bacterial pathogens in fish.

Keywords: Pseudomonas fluorescens, Pseudomonas putida, Aeromonas hydrophila, Klebsiella oxytoca, 16S rRNA gene, Antibiotic sensitivity

\section{INTRODUCTION}

Aquaculture is an emerging food producing sector that needs constant research with scientific, technical and innovation developments. Most infectious diseases of fish are opportunistic; this means that the simple presence of the pathogen in the environment of the fish is insufficient to cause a disease outbreak (Yanong and Francis-Floyd, 2002). Water pollution stresses farmed fish and increases susceptibility to infectious diseases, resulting in high mortalities (Sarmento et al., 2004). El-Serw fish farm is located on the southwest shore of Manzala Lake near El-Serw navigation canal, about $200 \mathrm{~km}$ northeast Cairo, the conservation of farmed fish from pollution is a major concern and agricultural drainage water is one of the most important sources of water for the El-Serw fish farm (Al-Afify et al., 2014). El-Serw fish farm suffers from poor water quality because water in aquaculture in Egypt is contaminated with the sewage disposal and agrochemical, in addition to exposure to high environmental factors leading to the outbreak of bacterial infection among fish, besides the sewage 
wastes discharged from the neighboring villages along Damietta without any treatment into the Damietta branch (Abdo, 2004).

Bacteria considered as a reliable indicator of pollution (Clark and Pagel, 1977) and it plays an important role in global ecosystems which are major factors in controlling water quality and determine the fate of environmental pollution (Atlas and Bartha, 1993).

Among the etiological agents of bacterial fish diseases Pseudomonas and Aeromonas are considered the most important fish pathogens. These bacteria are responsible for ulcer type diseases including ulcerative syndrome, bacterial hemorrhagic septicemia, tail and fin rot, and ascites (Paniagua et al., 1990). These bacteria have been reported to cause septicemia in O. niloticus in Egypt that was more prevalent during winter period (El-Sayyad et al., 2010). Fish species that are affected by A. hydrophila include freshwater fish; tilapia, catfish and common carp (Ullal et al., 2008; Abd-El-Rhman, 2009; Jeney, 2009 and Yin et al., 2009) and brackish and marine water fish; Meagre, Grouper, Sea bream and Mullet (El-Barbary, 2010 a,b). Although A. hydrophila is commonly considered as a secondary pathogen associated with disease outbreaks, it could also become a primary pathogen, causing outbreaks in fish farms with high mortality rates, resulting in severe economic losses to the aquaculture sector worldwide (Nielsen et al., 2001; Fang et al., 2004). The symptoms of A. hydrophila infection include swollen tissues, ascites, necrosis, red sores, ulceration, and hemorrhagic septicemia (Karunasagar et al., 1989; Azad et al., 2001).

Also, in Egypt, the genus Pseudomonas have been described as causative agents of diseases in fish, where $P$. fluorescens, $P$. angulliseptica, $P$. aeruginosa and $P$. putida were identified in various species of fish as etiological agents of pseudomonas septicemia (Sakar and Azza, 2008; Eissa et al., 2010; EL-Nagar, 2010).

Molecular techniques have provided faster results and high-resolution insights into the structure and diversity of bacterial communities (Kim et al., 2007; Wu et al., 2010). Bacteria can be identified by direct sequencing of the PCR-amplified bacterial $16 \mathrm{~S}$ rRNA followed by comparing this sequence with known sequences stored in GenBank (Clarridge, 2004). Thus, it has been widely used to measure the genetic diversity of biological samples (Baker et al., 2001). This approach has played a key role in identifying thousands of novel prokaryotic microorganisms and in improving our understanding of the level of microbial complexity. 16S rRNA contains variable and highly conserved regions, PCR primers targeting the conserved regions of rRNA amplify variable sequences of the rRNA gene (Relman, 1999; Buller, 2004). A universal PCR with primers RW01 and DG74 demonstrated to be a sensitive screening method for detection of bacterial pathogens (Greisen et al., 1994). 16S rRNA gene is an important tool when used alongside biochemical tests to identify microbes in the diagnostic laboratory (Buller, 2004). Phylogenetic analysis of $16 \mathrm{~S}$ rRNA allows identification of so far unknown organisms or bacterial isolates and provides appreciated data of the biodiversity from the respective ecosystem (Olsen $e t$ al., 1986; Ludwig et al., 1998). Microorganisms can be grouped together via similarities in their genes, which reflect their evolutionary relationships (Woese, 1987).

The aim of this study was isolation and identification of some of bacteria infecting fish of El-Serw fish farm during the harvest season using 16S rRNA assay to provide accurate detection of bacterial pathogens. 


\section{MATERIALS AND METHODS}

\section{Fish:}

A number of 155 apparently healthy and naturally infected fishes of different species; 65 Nile tilapia (O. niloticus), 55 catfish (Clarias gariepinus) and 35 mullet (Liza ramada) were collected from different ponds in El-Serw fish farm along the harvest season (December to March 2014-2015). These species are very important fish economically because they have high market value and have been successfully cultivated by fish farmers. These fishes were subjected to full clinical examination and recorded any abnormal signs.

\section{Culture and Incubation:}

Swabs from each organ (liver, kidney and gills) were inoculated into trypticase soy broth (TSB; Oxoid) and incubated at $37^{\circ} \mathrm{C}$ for $24 \mathrm{~h}$. A loopful of the obtained broth culture was streaked on the selective media Thiosulfate-citrate- bile salt- Sucrose (TCBS) agar (Vibrio selective media), Aeromonas Medium Base (Oxoid, Ltd.), Pseudomonas Agar Base (LabM, UK) and Yersinia Agar Base (LabM, UK), followed by incubation at $27 \pm 1^{\circ} \mathrm{C} / 24 \mathrm{hr}$ to isolate non Enterobacteriaceae bacteria. While, Yersinia selective agar media was used to isolate and detected Enterobacteriaceae bacteria such as Yersinia sp. Morphologically similar and dominant bacterial colonies were selected and streaked onto nutrient agar plates for $24 \mathrm{~h}$ at $27 \pm 1{ }^{\circ} \mathrm{C}$ in order to obtain pure cultures. Pure colonies were transferred to nutrient agar slants and stored at $4{ }^{\circ} \mathrm{C}$ for further identification.

\section{Identification of bacteria isolates:}

All purified isolates were identified by studying colony growth characteristics. Smears were prepared from the colonies and stained with Gram's stain and examined microscopically to demonstrate of morphology, arrangement and staining reaction of microorganism, also the motility of each isolate was tested. The bacteria isolates were identified according to schemes of biochemical reactions provided in Bergey's Manual of Systematic Bacteriology (Holt et al., 1994). After that, the selective isolates were tested for universal $16 \mathrm{~S}$ rRNA gene with complementary tests.

\section{Bacterial genomic DNA purification protocol:}

\section{DNA isolation from cultured bacteria:}

The pure isolates were incubated overnight in tryptic soy broth at $27 \pm 1{ }^{\circ} \mathrm{C}$, in order to isolate the DNA. Bacterial genomic DNA was extracted using Gene JET Genomic DNA Purification Kit (Thermo Scientific) according to the manufacturer's instruction. The eluted DNA was used as a template for PCR detection of universal 16S rRNA gene. Universal bacterial primers DG74 5'AGGAGGTGATCCAACCGCA-3' and RW01 5'-AACTGGAGGAAGGTGGGGAT3' were used for detection of 16S rRNA (Greisen et al., 1994). The locations of primers were 1521-1540 and 1170-1189, respectively.

\section{PCR and 16S rRNA gene sequencing:}

To identify bacteria, universal primers specific for 16S rRNA gene of eubacteria were used. PCR reactions were performed using $12.5 \mu \mathrm{l}$ of DreamTaq Green PCR Master Mix (2x) (Thermo Scientific \#K1082) with $2 \mu 1$ of Template DNA and water along with nuclease-free to reach the final volume of $25 \mu \mathrm{l}$ at room temperature. The amplification was performed using a thermal cycler (Biometra) with the following parameters: initial denaturation at $95^{\circ} \mathrm{C}$ for $5 \mathrm{~min}$, followed by 40 cycles of amplification (denaturation at $95^{\circ} \mathrm{C}$ for $30 \mathrm{~s}$, primer annealing at $58^{\circ} \mathrm{C}$ for $30 \mathrm{~s}$, extension at $72^{\circ} \mathrm{C}$ for $30 \mathrm{~s}$ ) and a final extension step of $72^{\circ} \mathrm{C}$ for $10 \mathrm{~min}$. After amplification, $10 \mu \mathrm{l}$ of the PCR sample was loaded on a $1.5 \%$ agarose gel in 
Trisacetate-EDTA containing ethidium bromide $(0.5 \mu \mathrm{g} / \mathrm{ml})$. The PCR product was purified with a QIAquick PCR purification kit and directly sequenced with a 3500/3500xL Genetic Analyzer (Applied Biosystems, at Faculty of Agriculture Research Park, Faculty Agriculture, Cairo University.

Phylogenetic analysis:

The 16S rRNA sequence of bacteria were analyzed and compared to all bacteria rRNA sequences by BLASTN (http://www.ncbi.nlm.nih.gov/blast) to find related species. The 16S rRNA genes of 27 related species selected from the GenBank database and their accession numbers are shown in the phylogenetic tree. Phylogenetic tree was constructed using MEGA6 (Tamura et al., 2013), performed using the Neighbor-Joining method (Saitou and Nei, 1987).

\section{Antibiotic susceptibility testing:}

The susceptibility was determined by the agar diffusion method using $6 \mathrm{~mm}$ diameter commercial discs (Oxoid Limited, Basing stoke, Hampshire, England) included the following antibiotics, $\left(\mu \mathrm{g} \mathrm{disc}^{-1}\right)$ : streptomycin $10(\mathrm{~S})$, cephazolin 30 (CZ), erythromycin $15(\mathrm{E})$, fusidic acid $10(\mathrm{FA})$, gentamycin $10(\mathrm{GN})$, oxytetracyclin 30 (OTC), ciprofloxacin 5 (CIP) and sulfamethoxazole 25 (SXT), nalidixic acid 30 (NA), norfloxacin 30 (NOR). Antibiotic sensitivity was tested on Mueller-Hinton agar plates, which were inoculated with $0.1 \mathrm{ml}$ of an 18-h old culture of the every test bacteria in glucose-supplemented $(1 \%)$ nutrient broth. Antibiotic discs were placed on the solid medium plates and incubated at $27 \pm 1{ }^{\circ} \mathrm{C}$ for $24 \mathrm{~h}$. Zones of inhibition formed around the discs were measured and antibiotic sensitivity was assayed from length of the diameter of the zones (in $\mathrm{mm}$ ). Zone diameters were interpreted as sensitive, intermediate and resistant according to CLSI (2010).

\section{RESULTS}

\section{The clinical and postmortem findings for naturally infected fish species:}

The clinical examination of the naturally infected fish species $(O$. niloticus, $C$. gariepinus and L. ramada) showed one or more of the following signs; hemorrhages in different areas of the body (fin base, mouth and anal region) some fish showed corneal opacity, exophthalmia, swelling of the abdomen, separated scales with ulcers of the skin and erosion of fins. In addition, gills were congested and in other cases were pale and swollen while liver, spleen, kidney and gall bladder showed congestion and enlargement.

\section{Bacteriological examination:}

After aseptic isolation from liver, kidney and gills of the suspected fish species and culturing on general and specific media, staining procedures and some biochemical tests it was clearly that the isolated species of bacteria from the studied fish were categorized into Gram negative bacteria. Some of the biochemical characters of the presumptive Aeromonas and Pseudomonas species were showed in Table 1. All isolates are Gram-negative rods, oxidase negative and motility. A according to schemes of biochemical reactions provided in Bergey's Manual of Systematic Bacteriology for identification, the obtained results indicate that Aeromonas sp. formed glucose, manitol, catalase and maltose and produced indol. While Pseudomonas species does not produce indol and formed glucose. Pseudomonas species showed variation in gelatin hydrolysis. 
Table 1: Some biochemical characterization of some Aeromonas and Pseudomonas species isolated from fish.

\begin{tabular}{|l|c|c|}
\hline \multirow{2}{*}{ Characteristics } & \multicolumn{2}{|c|}{ Isolates } \\
\cline { 2 - 3 } Gram stain & Aeromonas sp. & Pseudomonas sp. \\
\hline Cell shape & - & - \\
\hline motility & Short rods & Short rods \\
\hline Colony color & + & + \\
\hline Oxidase test & dark green & yellow-green \\
\hline Indol production & + & + \\
\hline Methyl red & + & - \\
\hline Vogus-proskour & - & + \\
\hline Gelatin hydrolysis & + & - \\
\hline Utilizationof Glucose & + & V \\
\hline Mannitol & + & - \\
\hline Maltose & + & + \\
\hline Catalase & + & + \\
\hline \multicolumn{1}{|c|}{+ Positive - Negative } & V Variable & + \\
\hline
\end{tabular}

\section{Prevalence of the isolated bacteria:}

A total of 59 bacterial colonies were recovered from the 155 examined fish. Selective isolation and preliminary identification reflected that 36 resembled Aeromonas sp., 21 resembled Pseudomonas sp. and 2 resembled Klebsilla sp. (Table 2).

A. hydrophila strains were isolated from $O$. niloticus $C$. gariepinus and $L$. ramada with a prevalence of $29 \%, 21.8 \%$ and $14.2 \%$, respectively. While Pseudomonas sp. isolated from the different organs with a prevalence of $13.8 \%, 14.5$ $\%$ and $11.4 \%$ from $O$. niloticus, $C$. gariepinus and $L$. ramada, respectively. On the other hand, Klebsiella oxytoca was isolated only from gills of $O$. niloticus with a prevalence of $3 \%$.

Table 2: Prevalence and distribution of bacteria among the examined fish.

\begin{tabular}{|c|c|c|c|c|c|c|c|c|c|}
\hline \multirow{3}{*}{$\begin{array}{l}\text { Number of } \\
\text { Fish species }\end{array}$} & \multicolumn{7}{|c|}{ Name and number (\%) of isolates } & \multirow{2}{*}{\multicolumn{2}{|c|}{ Total of isolates $(\%)$}} \\
\hline & \multicolumn{2}{|c|}{ Aeromonas sp. } & \multicolumn{2}{|c|}{ Pseudomonas sp. } & \multicolumn{2}{|c|}{ Klebsiella sp. } & \multirow{2}{*}{$\frac{\text { Vibrio sp. }}{\mathrm{N}}$} & & \\
\hline & $\mathrm{N}$ & $\%$ & $\mathrm{~N}$ & $\%$ & $\mathrm{~N}$ & $\%$ & & $\mathrm{~N}$ & $\%$ \\
\hline $\begin{array}{l}\text { O. niloticus } \\
(n=65)\end{array}$ & 19 & 29 & 9 & 13.8 & 2 & 3 & 0 & 30 & 46.1 \\
\hline $\begin{array}{l}\text { C. gariepinus } \\
(\mathrm{n}=55)\end{array}$ & 12 & 21.8 & 8 & 14.5 & - & - & & 20 & 36.3 \\
\hline $\begin{array}{l}\text { L. ramada } \\
(\mathrm{n}=35)\end{array}$ & 5 & 14.2 & 4 & 11.4 & - & - & 0 & 9 & 25.7 \\
\hline
\end{tabular}

$\mathrm{N}=$ number of isolates; $\%=$ Percentage of isolates calculated to the number of examined fish

\section{Analysis of 16S rRNA gene:}

Seven isolates were selected to identify by $16 \mathrm{~S}$ rRNA (1-7) and sequenced by 3500 Genetic Analyzer (Applied Biosystems) and were compared to those available in the GenBank database (Table 3 and Figs. 1). DG74 and RW01 primers were used to amplify of $16 \mathrm{~S}$ rRNA of bacterial isolates, with amplicon size 370 bp (Fig. 1).

Compared with GenBank database, the nucleotide sequences of 16S rRNA gene could detect the isolates of bacteria in the level species, according to levels of homology of nucleotide ranging from $98-100 \%$. 
Table 3: 16S rRNA based identification of isolates.

\begin{tabular}{|l|l|l|}
\hline No. of isolate & Isolates & Fish species \\
\hline 1 & A. hydrophila & O. niloticus \\
\hline 2 & A. hydrophila & C. gariepinus \\
\hline 3 & P. fluorescens & O. niloticus \\
\hline 4 & P. fluorescens & C. gariepinus \\
\hline 5 & P. fluorescens & L. ramada \\
\hline 6 & P. putida & L. ramada \\
\hline 7 & Klebsiella oxytoca & O. niloticus \\
\hline
\end{tabular}

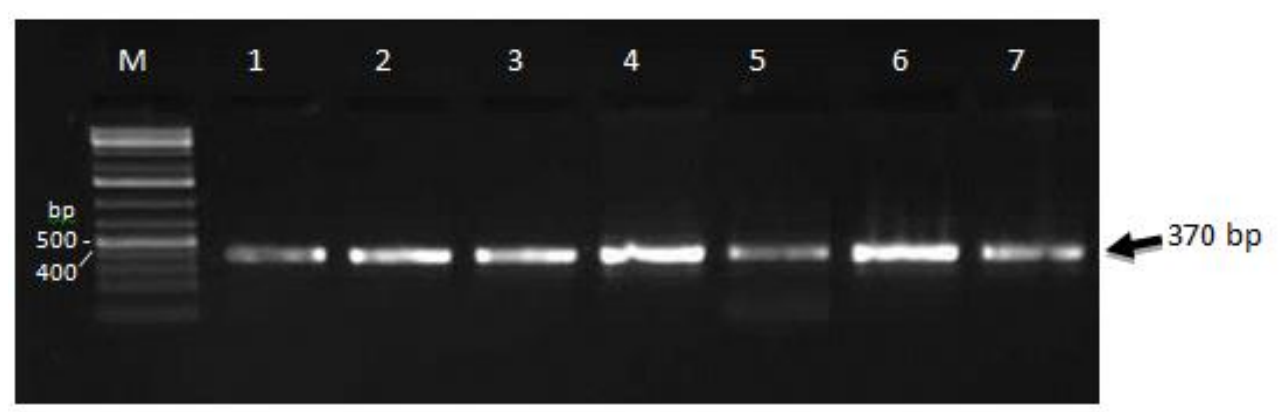

Fig. 1: Agarose (1.5\%) gel electrophoresis analysis of the PCR products from 16S rRNA gene of bacteria with universal primers (DG74 and RW01). Lane 1-7: Bacterial isolates.

The seven bacterial species belonged to three families Pseudomonadaceae, Aeromonadaceae and Enterobacteriaceae. The closer relationship among sequences of 16S rRNA was grouped to each other in the phylogenetic tree, where phylotypes were distributed in the branches (Fig. 2). The cluster of the genera Pseudomonas harbored four bacterial isolates; three bacterial isolates were clustered to, the type strain of Pseudomonas fluorescens and showed 99\% of homology with Pseudomonas fluorescens in GenBank (accession numbers KX527632, KX817232 and KF770987) however, one of bacterial isolate was grouped with Pseudomonas putida and was also closely related to Pseudomonas putida (GenBank accession no. KX817235). On the other hand, phylogenetic lineages in the branches of the genera of Aeromonas had two bacterial isolates which they were Aeromonas hydrophila and had an average nucleotide identity percentage, 98.5\%, with Aeromonas hydrophila (GenBank acc. nos. KJ781365, KU711812 and KU872254). The last bacterial isolate was clustered to Klebsiella oxytoca strains, showed $100 \%$ of similarity with K. oxytoca in GenBank (acc nos. KX911722 and HQ219863) and Klebsiella sp. (acc. no. KX500307). All of bacterial isolates were identified using $16 \mathrm{~S}$ rRNA and were confirmed by biochemical test.

\section{Antibiotic sensitivity:}

The sensitivity of bacterial strains that have been isolated from different fish species was included in Table (4). Results showed that the antibiotics resistance was common in all isolates except $K$. oxytoca. However, all bacterial isolates were found to be sensitive to at least 2 antibiotics (NOR, CIP and GN) and showed various resistance for OTC, S and STX. 


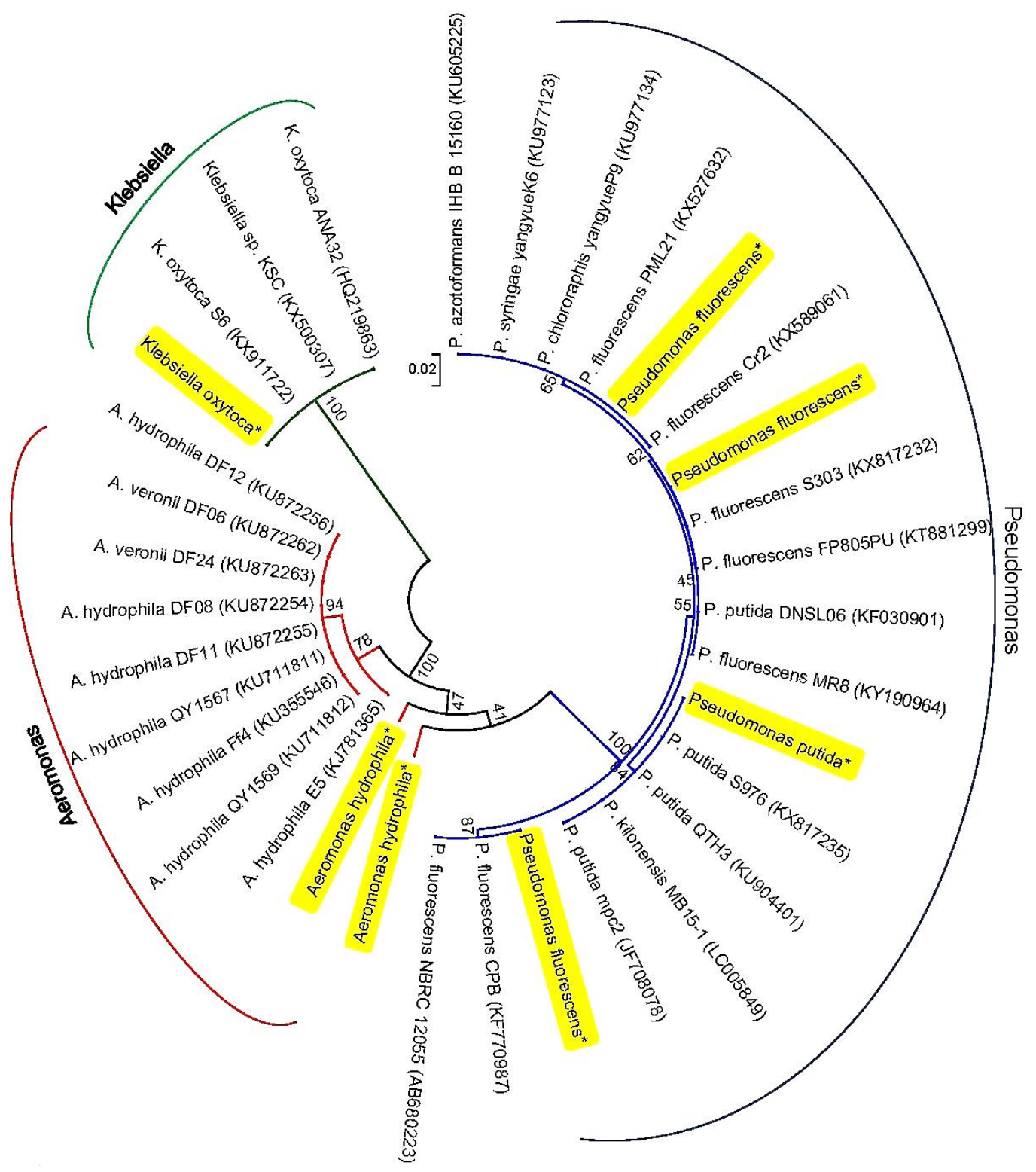

Fig. 2: The phylogenetic relationships, based on 16S rRNA gene sequences, were constructed by the neighbor-joining method. Numerals at nodes indicate bootstrap percentages derived from 1,000 replications. The bacterial isolates from this study designated with an asterisk and highlight. Accession numbers of 16S rRNA genes are shown in brackets.

Table 4: Antibiotic sensitivities of identified isolates.

\begin{tabular}{|l|c|c|c|c|c|c|c|c|c|c|}
\hline \multirow{2}{*}{ Isolates } & \multicolumn{9}{|c|}{ Antibiotic tested } \\
\cline { 2 - 13 } & NOR & NA & CIP & CZ & E & FA & GN & OTC & S & STX \\
\hline A. hydrophila 1 & S & R & S & R & R & R & S & R & R & I \\
\hline A. hydrophila 2 & S & I & S & R & I & I & S & S & R & S \\
\hline P. fluorescens 3 & S & R & S & I & R & R & S & S & S & R \\
\hline P. fluorescens 4 & S & R & S & S & R & R & I & R & S & I \\
\hline P. fluorescens 5 & S & R & I & R & R & R & S & I & I & I \\
\hline P. putida 6 & S & R & S & R & R & R & I & I & S & I \\
\hline K. oxytoca 7 & S & I & S & I & I & R & S & S & S & S \\
\hline
\end{tabular}

$\mathrm{NOR}=$ Norfloxacin, $\mathrm{NA}=$ Nalidixic Acid, $\mathrm{CIP}=$ Cirprofloxacin, $\mathrm{CZ}=$ Cephazolin, $\mathrm{E}=$ Erythromycin, FA= Fusidic acid, GN= Gentamycin, OTC= Oxytetracyclin, $\mathrm{S}=$ Streptomycin, $\mathrm{SXT}=$ Sulfamethoxazole. $\mathrm{R}=$ Resistant, $\mathrm{S}=$ Sensitive, $\mathrm{I}=$ Intermediate. 


\section{DISCUSSION}

The results in the Table (1) showed that, all Pseudomonas and Aeromonas species are characterized by Gram-negative motile rods with cytochrome oxidase and those findings agree with Altinok et al. (2006); El-Barbary (2010a,b); Nathan et al. (2011) whose reported that Pseudomonas species are Gram negative, oxidase positive, rod shaped bacteria that exist in the environment. $P$. fluorescens showed variation in some phenotypic tests such as gelatin hydrolysis where it has ability to hydrolyze gelatin in contrast to $P$. putida (Krieg and Holt, 1984).

Data in Table (2) showed that A. hydrophila was the most prevalent in the studied fish. This might be attributed to the harvest season, winter season, where Moustafa et al. (2010) reported the highest prevalence of A. hydrophila in winter season. Similarly, Pathak et al. (1988) recorded that the highest isolation rates of $A$. hydrophila occurred during late winter followed by a gradual decline in intensity during the summer and monsoon seasons. Popovic et al. (2000) mentioned that there was clear seasonality in the prevalence of $A$. hydrophila where there were no isolates recovered in the summer months. This could be attributed to the suppressed immunity to cultured fish caused by cold weather and low water temperature, which most warm water fish couldn't tolerate especially Tilapia spp. rendering fishes more vulnerable to different pathogens (Abdel-Hadi et al., 2008). In this study, the clinical and postmortem findings for naturally infected fishes showed hemorrhages, detachment of scales and ulcer on the skin, abdominal distention and fin rot. Similar lesions as hemorrhages over all the fish body especially at the base of fins, tail and fins rot, detachment of scales and skin ulceration and abdominal distention of naturally infected fishes by some of Aeromonas sp. and Pseudomonas sp. were recorded by Okaeme (1989); Karunasagar et al. (2001); Eissa et al. (2010); Hanna et al. (2014).

Klebsiella oxytoca was isolated only from gills of $O$. niloticus with a prevalence of 3\%, it is an indicator for sewage pollution, where Rajasekaran (2008) reported that Enterobacteraceae, as Klebsiella oxytoca, are considered as an indicator for sewage pollution and has been reported as opportunistic pathogen in fish. Pathogenic bacteria can be detected or diagnosed by using a variety of test methods, include growth on selective media followed by biochemical test, in addition to nucleic acid detection by polymerase chain reaction (PCR). The present study used PCR technique targeting 16S rRNA to detect bacterial isolates from infected fish through universal primers (RW01 and DG74) which has been reported as a sensitive screening method for detecting bacterial communities (Greisen et al., 1994; Teng et al., 2004).

The analysis of 16S rRNA gene gave a quick and accurate identification of bacteria (Genmoto et al., 1996; Kim and Jeong, 2001; Tringe and Hugenholtz, 2008; Tang et al., 2011). Many sets of primers have been designed to amplify different regions of $16 \mathrm{~S}$ rDNA and have been shown to have different sensitivities and specificities (Greisen et al., 1994). Moreover, phylogenetic analysis placed the bacterial isolates in three genera Pseudomonas, Aeromonas and Klebsiella based on homology, where bacteria with $<98.7 \%$ of similarity of $16 \mathrm{~S}$ rRNA gene sequence considered to be different species (Schleifer, 2009). It is worth mentioning that, weak evidence of identification of $A$. hydrophila, in this study, was due to amplification of short sequence of 16S rRNA gene. This observation was faced Jenkins et al. (2012) through analysis of large sequence of $16 \mathrm{~S}$ rRNA gene that improved species discrimination than short sequence. The results support the sensitivity of 16S rRNA 
approach could be affected by the size of the 16S rRNA gene fragment amplified. However, the specific media and biochemical test, confirmed the identification with 16S rRNA. The current and previous studies agreed with detection of different variable regions of the $16 \mathrm{~S}$ rRNA sequences could be a useful method to identify or use different techniques to confirm the identification of bacterial strains. The results of antimicrobial tests in the current study revealed that all tested strains were sensitive or intermediate to ciprofloxacin and norfloxacin and gentamycin, while other antibiotics that have been tested cannot be used to treat fish infected with these bacteria. Some of these results of antibiogram sensitivity are in agreement with those of Eissa et al. (2010) who reported that $P$. anguilliseptica, P. putida and $P$. aureginosa revealed that almost all of them were sensitive to Gentamicin, Erythromycin Novobiocin and Sulfa-trimethoprime. Also, Altinok et al. (2006) reported that $P$. putida has intrinsically high resistance to Chloramphenicol, Ampicillin, Erythromycin, Tetracycline, Rifampicin, Naladixic acid and Streptomycin. In another study, Darak and Barde (2015) reported that $P$. fluorescens was very sensitive to Kanamycin, Nalidixic acid, Gentamicin, Neomycin and less sensitive to Amikacin and Tetracycline, and Chlorophenicol. While El-Barbary (2010a), found that the isolates of A. hydrophila were sensitive to Oxytetracyclin, and showed varying resistance to Cephazolin, Erythromycin, Gentamicin and Sylfamethoxazole.

\section{CONCLUSIONS}

The results of this study concluded that, some of fish pathogenic bacteria are related to different taxonomic groups, have been isolated from different fish species, and identified by $16 \mathrm{~S}$ rRNA gene. The analysis of sequence of $16 \mathrm{~S}$ rRNA gene using universal primers (RW01 and DG74) succeeded in detecting four different bacterial isolates namely P. fluorescens, P. putida, A. hydrophila and Klebsiella oxytoca and showed that the performance of $16 \mathrm{~S}$ rRNA assay has the potential to create an important contribution to infection management by identification the bacterial pathogens in fish. In addition to, the antibiogram test showed that ciprofloxacin, norfloxacin and gentamycin could be used to treat fish infected with these strains.

\section{REFERENCES}

Abdel-Hadi, Y.M.; El-Bouhy, Z.M. and Diab, A.S. (2008). Prevalence of some bacterial agents affecting the gills of some cultured fishes in Egypt. Proceeding of the 30th Malaysian Symposium on Microbiology, August 16-19, 2008, Kuantan, Malaysia.

Abd-El-Rhman, A.M. (2009). Antagonism of Aeromonas hydrophila by propolis and its effect on the performance of Nile tilapia, Oreochromis niloticus. Fish Shellfish Immunol., 27:454-9.

Abdo, M.H. (2004). Seasonal variations of some heavy metals in macrophytes and water of Damietta branch, River Nile, Egypt. Egypt J Aquat Biol Fish, 8:195211

Al-Afify, F.D.; Osman, M.E. and Elnady, M. (2014). Ecological Studies on El-Serw Fish Farm, Egypt: Drainage Water Quality, Sediment Analysis and Heavy Metals Pollution in Nile Delta. Farms Paperback- LAP LAMBERT Academic Publishing (2014-06-16). 200 pp. 
Altinok, I.; Kayis, S. and Capkin, E. (2006). Pseudomonas putida infection in rainbow trout. Aquaculture, 261: 850-855.

Atlas, R.M. and Bartha, R. (1993). Microbial ecology: Fundamentals and Applications, 3rd Edition, Redwood City, Benjamin.

Azad, I.S.; Rajendran, K.V.; Rajan, J.J.S.; Vijayan, K.K. and Santiago, T.C. (2001). Virulence and histopathology of Aeromonas hydrophila (Sah 93) in experimentally infected tilapia, Oreochromis mossambicus (L.). J. Aquac. Trop., 6: 265- 75.

Baker, G.C.; Gaffar, S.; Cowan, D.A. and Suharto, A.R. (2001). Bacterial community analysis of Indonesian hot springs. FEMS Microbiol. Lett., 200: 103-109.

Buller, N.B. (2004). Bacteria from Fish and Other Aquatic Animals. A Practical Identification Manual. Cabi Publishing, UK.

Clark, I.A. and Pagel, J.E. (1977). Pollution Indicator Bacteria associated with Municipal Raw and Drinking Water Supplies. Can. J. Microbiol., 28: 465-470.

Clarridge, J.E., III (2004). Impact of 16S rRNA gene sequence analysis for identification of bacteria on clinical microbiology and infectious diseases. Clin Microbiol Rev., 17: 840-862.

CLSI, (2010). Performance Standards for Antimicrobial Susceptibility Testing, 20th Informational Supplement. Clinical and Laboratory Standards Institute, M100S20 \& M100-S-20-U.

Darak, O. and Barde, R.D. (2015). Pseudomonas fluorescens associated with bacteria disease in Catla catla in Marathwada region Maharashtra. Int J Adv Biotechnol Res., 6: 189-195

Eissa, N.M.E.; Abou El-Ghiet, E.N.; Shaheen, A. and Abbass, A. (2010). Characterization of Pseudomonas Species Isolated from Tilapia "Oreochromis niloticus" in Qaroun and Wadi-El-Rayan Lakes, Egypt. Glob. Vet., 5: 116-121.

EL-Barbary, M.I. (2010a). Some clinical microbiological and molecular characteristics of Aeromonas hydrophila isolated from various naturally infected fishes. Aquac Int., 18:943-954.

EL-Barbary, M.I. (2010b). Pathogenic characteristics and molecular identification of Aeromonas hydrophila isolated from some naturally infected cultured fishes. Egyptian Journal of Aquatic Research, 36(2): 345-356.

El-Nagar, R.M.A. (2010). Bacteriological studies on pseudomonas microorganisms in cultured. MSc. thesis, Fac. Vet. Med., Zag. University.

El-Sayyad, H.I.; Zaki, V.H.; El-Shebly, A.M. and El-Badry, D.A. (2010). Studies on the effects of bacterial diseases on skin and gill structure of Clarias gariepinus in Dakahlia Provinence, Egypt. Annal. Biol. Res., 4 (1): 106-118.

Fang, H.M.; Ge, R. and Sin, Y.M. (2004). Cloning, characterisation and expression of Aeromonas hydrophila major adhesin. Fish Shellfish Immunol., 16:645-58.

Genmoto, K.; Nishizawa, T.; Nakai, T. and Muroga, K. (1996). 16S rRNA targeted RT-PCR for the detection of Vibrio penaeicida, the pathogen of cultured kuruma prawn Penaeus japonicus. Dis Aquat Organ., 24: 185-189

Greisen, K.; Loeffelholz, M.; Purohit, A. and Leong, D. (1994). PCR primers and probes for the $16 \mathrm{~S}$ ribosomal RNA gene of most species of pathogenic bacteria, including bacteria found in cerebrospinal fluid. J. Clin. Microbiol., 32(2):335351.

Hanna, M.I.; El-Hady, M.A.; Ahmed, H.A.; Elmeadawy, S.A. and Kenwy, A.M. (2014). A contribution on Pseudomonas aeruginosa infection in African Catfish (Clarias gariepinus). Res J Pharm Biol Chem Sci., 5: 575-588. 
Holt, J.G., Krieg, N.R., Sneath, P.H.A., Staley, J.T. and Williams, S.T. (1994). Bergey's Manual of Determinative Bacteriology, 9th edn. Baltimore: Williams \& Wilkins

Jeney, Z., Rácz, T., Thompson, K.D.;Poobalane, S.;Ardó, L.; Adams, A. et al. (2009). Differences in the antibody response and survival of genetically different varieties of common carp (Cyprinuscarpio L.) vaccinated with a commercial Aeromonas salmonicida /A. hydrophila vaccine and challenged with $A$. hydrophila. Fish Physiol.Biochem., 35: 677-82.

Jenkins, C., Ling, C.L., Ciesielczuk, H.L., Lockwood, J., Hopkins, S., Mc Hugh, T. D., Gillespie, S.H., and Kibbler, C.C. (2012). Detection and identification of bacteria in clinical samples by 16S rRNA gene sequencing: comparison of two different approaches in clinical practice. J Med Microbiol., 61: 483-488.

Karunasagar, I.; Rosalind, G.M.; Karunasagar, I. and Gopal Rao, K. (1989). Aeromonas hydrophila septicaemia of Indian major carps in some commercial fish farms of West Godavari District, Andhra Pradesh. Curr. Sci., 58:1044-5.

Kim, D.H.; Brunt, J. and Austin, B. (2007). Microbial diversity of intestinal contents and mucus in rainbow trout (Oncorhynchus mykiss). J Appl Microbiol., 102: 1654- 1664.

Kim, M.S. and Jeong, H.D. (2001). Development of 16S rRNA targeted PCR methods for the detection and differentiation of Vibrio vulnificus in marine environments. Aquacul., 193: 199-211.

Krieg, N.R. and Holt, J.G. (1984). Bergey's Manual of Systematic Bacteriology, vol. 1.Williams and Wilkins, Baltimore, MD, p. 964

Ludwig, W.; Strunk, O.; Klugbauer, S.; Klugbauer, N.; Weizenegger, M.; Neumaier, J.; Bachleitner, M. and Schleifer, K.H. (1998). Bacterial phylogeny based on comparative sequence analysis. Electrophoresis, 19: 554-568

Moustafa, M.; Laila, A.M.; Mahmoud, M. A.; Soliman, W.S. and El-gendy, M. Y. (2010). Bacterial Infections Affecting Marine Fishes in Egypt. Journal of American Science, (6): 603 - 612.

Nathan, P.; Rathinam, X.; Kasi, M.; Rahman, Z.A. and Subrama-niam, S. (2011). A pilot study on the isolation and biochemical characterization of Pseudomonas from chemical intensive rice ecosystem. Afr J Biotechnol., 10: 12653-12656.

Nielsen, M.E.; Hoi, L.; Schmidt, A.S.; Qian, D.; Shimata, T.; Shen, J.Y. and Larsen, J.L. (2001). Is Aeromonas hydrophila the dominant motile Aeromonas species that cause disease outbreaks in aquaculture production in the Zhejiang Province of China?. Dis. Aquat. Organ., 22: 23-29.

Okaeme, A.N. (1989). Bacteria associated with mortality in tilapias, Heterobranchus bidorsalis, and Clarias lazera in indoor hatcheries and outdoor ponds. J Aquacult Trop., 4: 143-146.

Olsen, G.J.; Lane, E.J.; Giovannoni, S.J.; Pace, N.R. and Stahl, D.A. (1986). Microbial ecology and evolution: a ribosomal RNA approach. Annual Review of Microbiology, 40: 331-355.

Paniagua, C.; Rivero, O.; Anguita, J. and Naharro, G. (1990). Pathogenicity Factors and Virulence for Rainbow Trout (Salmo gairdneri) of Motile Aeromonas spp. Isolated from a River. J Clin Microbiol., 28(2):350-355.

Pathak, S.P.; Bhattacherjee, J. W.; Kalra, N. and Chandra, S. (1988). Seasonal distribution of A. hydrophila in river water and isolation from river fish. J. Appl. Bacteriol., 65:347-52. 
Popovic, T. N.; Teskeredzic, E.; Perovic, I. S. \& Rakovac, R. C. (2000): A. hydrophila isolated from wild fresh water fish in Croatia.Vet. Rsearch communic., 24: 371377.

Rajasekaran, P. (2008). Enterobacteriaceae group of organisms in sewage-fed fishes. Advanced Biotech, 8, 12-14

Relman, D. A. (1999). The search for unrecognized pathogens. Science. 284:13081310.

Saitou, N., and Nei, M. (1987). The neighbor-joining method: A new method for reconstructing phylogenetic trees. Mol Biol Evol., 4:406-425.

Sakar, S.F.M. and Azza, M.M.A. (2008). Contribution on Pseudomona septicemia caused by Ps. anguilliseptica in cultured Oreochromis niloticus. Fish Diseases Dept., Central lab for Aquaculture Research, Abbassa, Agriculture Research Center, Egypt, 1177-1197.

Sarmento, A.; Guilhermino, L. and Afonso, A. (2004). Mercury chloride effects on the function and cellular integrity of sea bass (Dicentrarchus labrax) head kidney macrophages. Fish Shellfish Immunol., 17(5):489- 98.

Schleifer, K.H. (2009). Classification of Bacteria and Archaea: Past, present and future. Syst. Appl. Microbiol., 32; 533-542.

Tamura, K.; Stecher, G.; Peterson, D.; Filipski, A. and Kumar, S. (2013). MEGA6: Molecular Evolutionary Genetics Analysis version 6.0. Mol Biol Evol., 30: $2725-2729$.

Tang, J.; Zheng, A.; Bromfield, E.S.P.; Zhu, J.; Li, S.; Wang, S.; Deng, Q., and Li, P. (2011). 16S rRNA gene sequence analysis of halophilic and halotolerant bacteria isolated from a hypersaline pond in Sichuan, China. Ann Microbiol., 61:375-381.

Teng, L.; Hsueh,P.; Huang, Y. and Tsai, J. (2004). Identification of Bacteroides thetaiotaomicron on the Basis of an Unexpected Specific Amplicon of Universal 16S Ribosomal DNA PCR. J. Clin. Microbiol., 42: 1727-1730.

Tringe, S.G., and Hugenholtz, P. (2008). A renaissance for the pioneering 16S rRNA gene. Curr Opin Microbiol., 11:442-6.

Ullal, A.J.; Litaker, R.W. and Noga, E.J. (2008). Antimicrobial peptides derived from hemoglobin are expressed in epithelium of channel catfish (Ictalurus punctatus, Rafinesque). Dev. Comp.Immunol., 32:1301-12.

Woese, C.R. (1987). Bacterial evolution. Microbiol. Rev., 51: 221-71.

Wu, S.; Gao, T.; Zheng, Y.; Wang, W.; Cheng, Y., et al. (2010) Microbial diversity of intestinal contents and mucus in yellow catfish (Pelteobagrus fulvidraco). Aquacul., 303: 1-7.

Yanong, R.P.E. and Floyd, R.F. (2002). Streptococcal infections of fish. Florida Cooperative Extension Service. IFAS, University of Florida, pp. 1-5. Circular, FA0 57.

Yin, G.; Ardó, L.; Thompson, K.D.; Adams, A.; Jeney, Z. and Jeney, G. (2009). Chinese herbs (Astragalus radix and Ganoder malucidum) enhance immune response of carp, Cyprinus carpio, and protection against Aeromonas hydrophila. Fish Shellfish Immunol., 26:140-5. 


\title{
ARABIC SUMMARY
}

\author{
العزل و التوصيف الجزيئي لمسببات الامراض البكتيريه في مزرعه السرو السمكيه، مصر

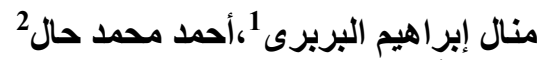

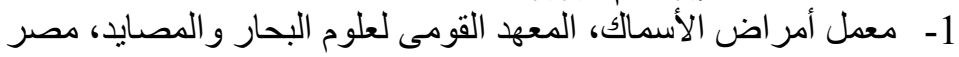

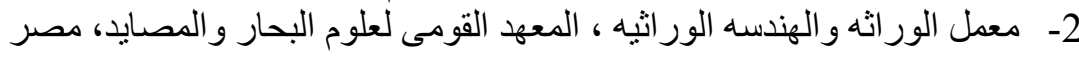

تم تقييم الحاله البكتريولوجية لأسماك مزرعه السرو خلال فتره حصاد الأسماك (ديسمبر - مارس

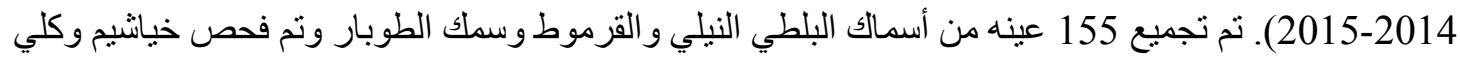

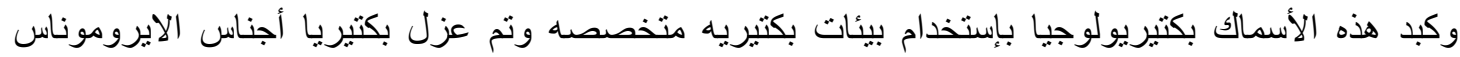

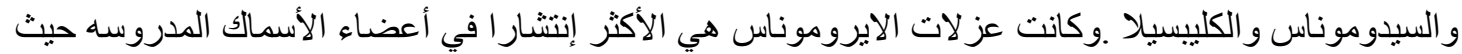

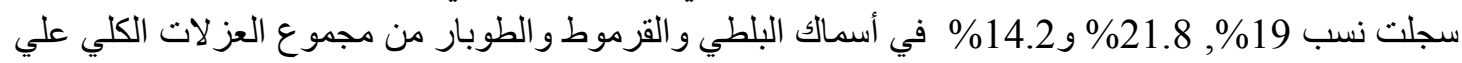

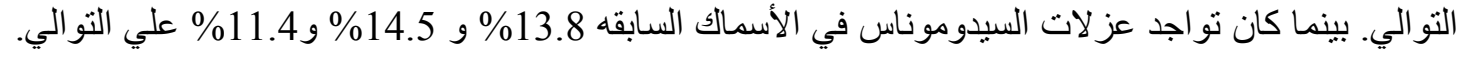

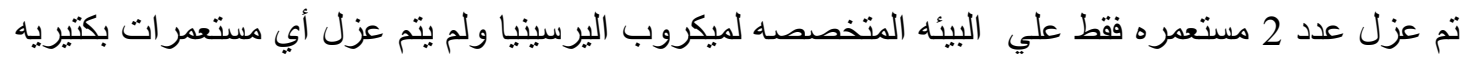

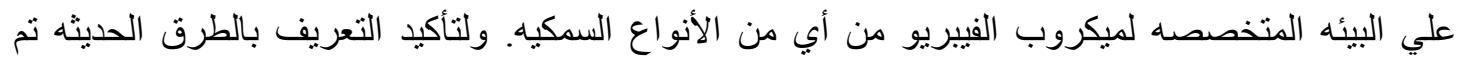

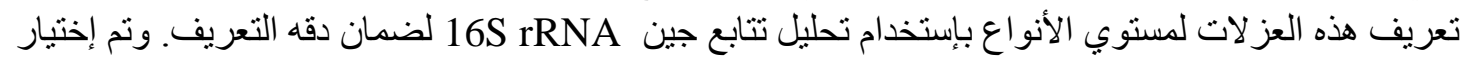

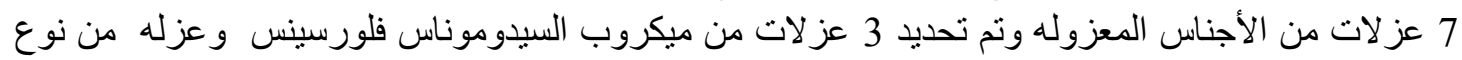

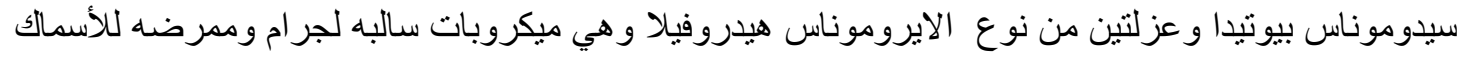

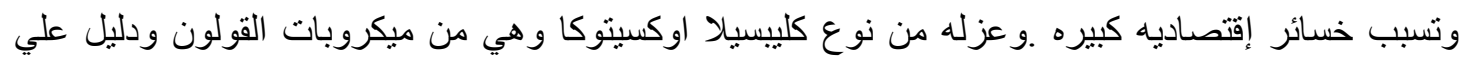

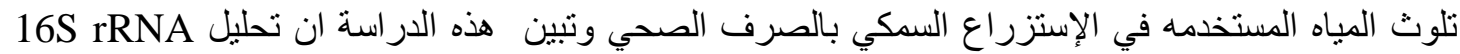

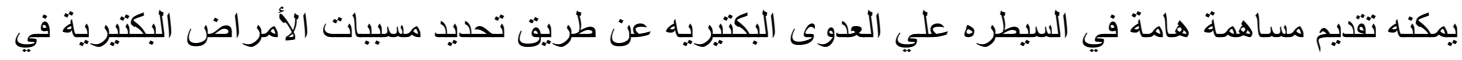

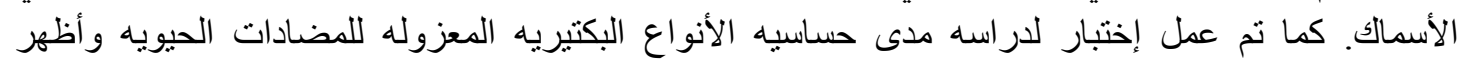

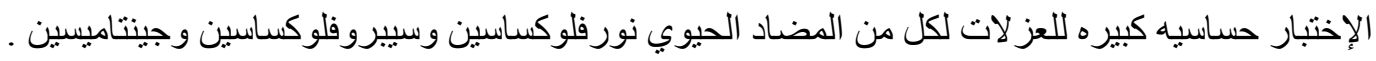

